\title{
PEMBUATAN SEDIAAN SERBUK INSTAN DAUN SIRSAK (Annona muricata L.) DIKOMBINASIKAN DENGAN SARI BUAH NANAS (Ananas comosus L.) UNTUK MENCEGAH PENINGKATAN KADAR ASAM URAT
}

\author{
Suci Tri Yuliani ${ }^{*}$, Risa Kota Putra ${ }^{2}$, Dewi Ratnasari ${ }^{3}$ \\ 1,2,3 Sekolah Tinggi Ilmu Kesehatan Holistik \\ *Korespondensi: Jl. Veteran No. 272 Ciseureuh Purwakarta. Email: sucitriyuliani@gmail.com
}

\begin{abstract}
ABSTRAK
Latar belakang: Perubahan pola makan berpotensi menimbulkan penyakit, salah satu penyakitnya yaitu hipeururisemia. Hiperurisemia merupakan suatu keadaan meningkatnya produksi asam urat didalam tubuh yang disebabkan oleh metabolisme purin abnormal dan menurunnya eksresi asam urat. Pengobatan secara tradisional dengan tanaman obat dapat menjadi pilihan untuk mengatasi asam urat, karena efek sampingnya yang dimiliki tanaman lebih rendah dibandingkan obat-obatan kimia, selain itu lebih mudah diperoleh.
\end{abstract}

Tujuan: Penelitian ini bertujuan untuk mengetahui cara pembuatan sediaan serbuk instan daun sirsak (Annona muricata L.) yang dikombinasikan dengan sari buah nanas (Ananas comosus L.) yang bermanfaat bagi kesehatan.

Metode: Penelitian ini menggunakan metode penelitian tindakan. Instrumen penelitian yang digunakan adalah lembar observasi dan kuisioner. Sediaan dibuat dengan perbandingan formulasi ektrak daun sirsak dan sari buah nanas (F1, 125ml:375ml; F2, 250ml:250ml dan F3, 375ml:125ml) dan masing-masingnya ditambahkan gula sebanyak $200 \mathrm{gr}$.

Hasil: Penelitian menunjukkan formulasi sediaan serbuk instan yang berhasil dibuat dengan hasil terbaik yaitu formulasi F3 dengan perbandingan $375 \mathrm{ml}$ ekstrak daun sirsak, $125 \mathrm{ml}$ sari buah nans, dan 200gr gula. Pengamatan secara organoleptik sediaan serbuk instan stabil dalam penyimpanan selama tiga minggu.

Simpulan: Sediaan serbuk instan formulasi F3 sampel kedua lebih disukai dan diterima masyarakat karena warna yang lebih baik atas derajat suhu pemanasan pembuatan yang lebih tepat.

Kata kunci: Daun sirsak, Buah Nanas, Serbuk instan

\begin{abstract}
Background: Changes in diet have the potential to cause disease, one of which is hypeururicemia. Hyperuricemia is a condition of increased uric acid production in the body caused by abnormal purine metabolism and decreased uric acid excretion. Traditional treatment with medicinal plants can be an option to treat gout, because the side effects of plants are lower than chemical drugs, besides being easier to obtain.

Purpose: This study aims to determine how to make instant powder formulation of soursop leaves (Annona muricata L.) combined with pineapple juice (Ananas comosus L.) which is beneficial for health.

Methods: This research uses action research method. The research instruments used were observation sheets and questionnaires. The preparations were made by comparing the soursop leaf extract formulation and pineapple juice (F1, 125ml: $375 \mathrm{ml} ; \mathrm{F2}, 250 \mathrm{ml}: 250 \mathrm{ml}$ and F3, 375 $\mathrm{ml}: 125 \mathrm{ml}$ ) and added $200 \mathrm{gr}$ of sugar each.

Results: The study showed that the instant powder formulation that was successfully prepared with the best results was the F3 formulation with a ratio of $375 \mathrm{ml}$ of soursop leaf extract, $125 \mathrm{ml}$ of nans fruit juice, and $200 \mathrm{~g}$ of sugar. Organoleptic observations of instant powder preparations were stable in storage for three weeks.
\end{abstract}


Conclusion: The second sample F3 instant powder formulation was preferred and accepted by the public because of the better color due to the more precise heating temperature of the manufacturing process.

Keywords: soursop leaves, pineapple fruit, instant powder

\section{PENDAHULUAN}

Peningkatan usia harapan hidup dan status gizi masyarakat pada dekade terakhir ini telah menyebabkan transisi pola kebiasaan hidup termasuk pola makan. Perubahan pola makan yang dimaksud yaitu perubahan dari pola makan tradisional yang mengandung banyak karbohidrat dan serat sayuran menjadi pola makan dengan komposisi banyak protein, lemak dan garam ${ }^{[1]}$. Perubahan pola makan ini berpotensi menimbulkan penyakit, salah satu penyakitnya yaitu hipeururisemia ${ }^{[2]}$. Hasil survei WHO-ILAR Copcord (World Health Organization-International League of Associations for Rheumatology Community Oriented Program for Control of Rheumatic Disease) pada penelitian yang dilakukan oleh ${ }^{[3]}$ di pedesaan Sulawesi Utara dan Manado menemukan hubungan asam urat dengan pola konsumsi dan gaya hidup, diantaranya kebiasaan mengkonsumsi alkohol dan makanan kaya purin yang dapat meningkatkan kadar asam urat.

Hiperurisemia merupakan suatu keadaan meningkatnya produksi asam urat didalam tubuh yang disebabkan oleh metabolisme purin abnormal dan menurunnya eksresi asam urat. Asam urat dihasilkan dari proses metabolisme sel yang berfungsi untuk memelihara kelangsungan hidup ${ }^{[4]}$. Berdasarkan hasil Riset Kesehatan Dasar (Riskesdas) tahun 2018 prevalensi penyakit sendi yang termasuk asam urat berdasarkan diagnosis di Indonesia sebesar $7,3 \%$. Prevalensi penderita asam urat tertinggi terjadi di Aceh yang mencapai 13,3\%. Data laporan Riskesdas 2018 menyebutkan bahwa penderita asam urat meningkat seiring bertambahnya usia pada lansia diantaranya $6,1 \%$ pria dan $8,5 \%$ wanita. Data tersebut menunjukkan bahwa wanita lansia dominan mengalami nyeri sendi dari pada pria lansia.
Pengobatan secara tradisional dengan tanaman obat dapat menjadi pilihan untuk mengatasi asam urat, karena efek sampingnya yang dimiliki tanaman lebih rendah dibandingkan obat-obatan kimia, selain itu lebih mudah diperoleh. Salah satunya daun sirsak (Annona muricata L.), yang bagian daunnya adalah yang paling berkhasiat untuk mengatasi nyeri akibat penyakit asam urat ${ }^{[5]}$. Kandungan senyawa yang paling penting pada daun sirsak adalah tannin, resin, dan crytallizable magostine yang mampu mengatasi nyeri sendi pada penyakit hiperurisemia (asam urat)[6]. Senyawa yang terkandung dalam daun sirsak tersebut berfungsi sebagai analgesik yang kuat serta bersifat sebagai antioksidan. Kombinasi sifat analgesik dan antiinflamasi mampu mengurangi kadar asam urat ${ }^{[7]}$. Hasil penelitian ${ }^{[8]}$ menunjukkan bahwa efek senyawa tannin, resin, crytallizable dari daun sirsak dapat meredakan, mengurangi bengkak dan rasa nyeri sendi pada penderita asam urat.

Tumbuhan lain yakni buah nanas (Ananas comosus L.) mengandung enzim breomelain yang mempunyai efek antiinflamasi dan membantu pencernaan protein. Oleh karena itu, baik dikonsumsi bagi penderita radang sendi yang disebabkan karena meningkatnya kadar asam urat ${ }^{[9]}$. Berdasarkan penelitian yang dilakukan ${ }^{[10]}$ terdapat pengaruh konsumsi jus nanas terhadap penurunan kadar asam urat pada lansia di Panti Werdha Mojopahit Mojokerto mendapatkan nilai $\mathrm{p}=0,000(\mathrm{a}=$ $0,05)$.

Berdasarkan pada literatur tentang sari buah nanas dan daun sirsak itulah penulis tertarik menghadirkan sediaan yang mengkombinasikan kedua tumbuhan tersebut berupa sediaan serbuk instan melalui penelitian yang berjudul "Pembuatan Sediaan Serbuk Instan Daun Sirsak dikombinasikan dengan Sari Buah 
Nanas untuk Mencegah Peningkatan Kadar Asam Urat" yang dibuat menggunakan metode maserasi dengan air.

\section{METODE PENELITIAN}

Penelitian ini menggunakan metode penelitian tindakan (action reseach) yang merupakan salah satu metode yang digunakan untuk memperoleh pengetahuan sekaligus melakukan tindakan untuk menemukan upaya-upaya perubahan dalam masyarakat yang sesuai dengan kondisi dan kebutuhan masyarakat ${ }^{[11]}$. Penelitian tindakan yang dilakukan oleh peneliti yaitu menggunakan daun sirsak pada pembuatan sediaan serbuk instan dan mengkombinasikannya dengan buah nanas yang diamati stabilitas fisiknya secara organoleptik dan dilakukan uji kesukaan kepada masyarakat terhadap hasil sediaan serbuk instan.

Teknik pengumpulan data yang digunakan pada penelitian ini yaitu observasi kualitatif karena peneliti hanya mengamati, melihat, dan mencatat hasil pengamatan fisik sediaan untuk memperoleh data dari uji organoleptik dan memperoleh data dari uji kesukaan yang dilakukan dengan cara wawancara dan dokumentasi.

Peralatan yang digunakan dalam penelitian ini adalah blender juicer, pisau, gelas ukur plastik $1000 \mathrm{ml}$, wajan stainless, sutil kayu pengaduk, kompor gas, saringan plastik, baskom plastik, pengayak 100 mesh, dan timbangan digital.

Bahan yang digunakan dalam penelitian ini adalah daun sirsak yang masih segar dan sudah tua sebanyak 80 gram, buah nanas yang sudah matang sebanyak 450 gram, gula pasir murni yang berwarna putih sebanyak 600 gram, dan air bersih.

\section{PERLAKUAN PENELITIAN}

$\mathrm{F} 1$ = Sari buah nanas $375 \mathrm{ml}$, ektrak daun sirsak $125 \mathrm{ml}$, dan gula pasir $200 \mathrm{gr}$ $\mathrm{F} 2$ = Sari buah nanas $250 \mathrm{ml}$, ekstrak daun sirsak $250 \mathrm{ml}$, dan gula pasir $200 \mathrm{gr}$ F3 = Sari buah nanas $125 \mathrm{ml}$, ekstrak daun sirsak $375 \mathrm{ml}$, dan gula pasir $200 \mathrm{gr}$.

\section{TAHAP PELAKSANAAN}

Masukan ekstrak cair daun sirsak dan sari buah nanas yang sudah disiapkan kedalam wajan. Masak campuran tersebut dengan api kecil sambil di aduk-aduk. Setelah campuran terlihat kental masukan gula pasir sedikit demi sedikit. Terus aduk sediaan sampai campuran tersebut menjadi gumpalan yang mengkristal kemudian angkat dan dinginkan. Gumpalan dihancurkan dengan blender sampai berbentuk butiran halus. Butiran-butiran tersebut kemudian diayak menggunakan alat pengayak 100 mesh agar kehalusan serbuk instan yang didapat menjadi sama. Timbang hasil sediaan serbuk instan daun sirsak dan sari buah nanas. Masukan masing-masing hasil timbangan kedalam plastik yang higienis.

\section{HASIL PENELITIAN}

Sediaan serbuk instan kombinasi bahan berkhasiat dari daun sirsak dengan sari buah nanas yang dibuat pada penelitian ini ada dalam 3(tiga) formulasi yaitu F1, F2, dan F3, dengan hasil sebagai berikut:

1. F1: Kombinasi bahan yang terdiri dari $375 \mathrm{ml}$ sari buah nanas dengan $125 \mathrm{ml}$ ekstrak daun sirsak, dilihat secara visual kombinasi ini menghasilkan sediaan berwarna coklat tua yang lengket seperti selai. Pada saat proses pembuatan, pengadukan terus menerus dilakukan namun sediaan tersebut terjadi penggumpalan atau penghangusan dan tidak menjadi serbuk. Hal ini disebabkan karena sari buah nanas yang digunakan lebih banyak dibandingkan dengan ekstrak daun sirsak, oleh sebab itu berdasarkan teori yang menyatakan bahwa buah nanas mempunyai kandungan air sebanyak 90\% dan peningkatan kematangan buah akan meningkatkan kadar gula yang terdapat didalamnya[12]. Sifat gula tersebut sangat dipengaruhi oleh PH, jika PH larutan rendah (asam) maka proses kristalisasi tidak akan terbentuk dan larutan menjadi lengket.

2. F2: Kombinasi bahan yang terdiri dari $250 \mathrm{ml}$ sari buah nanas dengan $250 \mathrm{ml}$ ekstrak daun sirsak, setelah proses pembuatan dilihat secara visual kombinasi ini menghasilkan sediaan berwarna coklat tua yang lengket. Pada saat proses 
pembuatan, pengadukan terus menerus dilakukan namun sediaan tersebut seperti adonan yang mengental dan terjadi penghangusan. Penghancuran adonan yang dilakukan dalam keadaan dingin, akan sulit karena adonan tersebut telah mengeras. Hal ini disebabkan karena sari buah nanas yang digunakan sebanding dengan ektrak daun sirsak, oleh sebab itu kedua bahan tersebut tidak dapat tercampur sempurna. Berdasarkan teori yang menyatakan bahwa buah nanas mempunyai kandungan air sebanyak $90 \%$ dan peningkatan kematangan buah akan meningkatkan kadar gula yang terdapat didalamnya[12]. Sifat gula tersebut sangat dipengaruhi oleh $\mathrm{PH}$, jika PH larutan rendah (asam) maka proses kristalisasi tidak akan terbentuk dan larutan menjadi lengket.

3. F3: Kombinasi bahan yang terdiri dari $125 \mathrm{ml}$ sari buah nanas dengan $375 \mathrm{ml}$ ekstrak daun sirsak, sediaan ini berhasil membentuk serbuk dengan cara sederhana yaitu kristalisasi. Berdasarkan cara tersebut pada pemanfaatan sifat gula pasir yang dipanaskan akan mencair dan bercampur dengan bahan lainnya, ketika larutan menguap akan terbentuk kembali menjadi butiran-butiran padat. Butiran serbuk yang terbentuk harus dihancurkan atau dihaluskan menggunakan blender hingga menjadi serbuk yang lembut. Serbuk yang telah dihaluskan, kemudian diayak menggunakan alat pengayak 100 mesh agar kehalusan serbuk instan yang didapat menjadi sama. Formulasi bahan yang terdiri dari $125 \mathrm{ml}$ sari buah nanas dengan $375 \mathrm{ml}$ ekstrak daun sirsak tersebut, dibuat sebanyak 3 (tiga) sampel untuk diuji stabilitas sediaan secara organoleptik.

Hasil akhir penimbangan sediaan yang sesuai dengan hasil penelitian, dimana pada pembuatan serbuk instan dengan perlakuan F3 yang didapat dari ketiga sampel yaitu sampel 1 sebanyak $157 \mathrm{gr}$ (FS1), sampel 2 sebanyak 168gr (FS2), dan sampel 3 sebanyak 162gr (FS3).

Berdasarkan hasil yang dibuat, warna sediaan serbuk instan pada sampel FS1 terlihat berwarna coklat. Hal ini disebabkan karena pada saat proses pembuatan, api yang digunakaan terlalu besar sehingga warna serbuk lebih gelap dibandingkan dengan sampel FS2 dan sampel FS3. Selama proses pembuatan, sediaan serbuk instan diusahakan sambil terus diaduk-aduk dalam wajan dengan api kecil agar pembuatan sediaan tetap stabil dan sediaan menjadi butiran-butiran padat yang mengkristal.

Berdasarkan hasil dari tiga formulasi sediaan yang dirancang pada penelitian ini, perlakuan F1 dan F2 gagal dibuat menjadi serbuk instan. Oleh sebab itu, hanya sediaan dengan perlakuan F3 yang dilanjutkan untuk pengamatan uji organoleptik dan uji kesukaan, yang selanjutnya ditandai dengan sebagai sampel FS1, FS2 dan FS3.

Tabel 1 Hasil Uji Organoleptik Selama 3 Minggu

\begin{tabular}{|c|c|c|c|c|c|c|c|c|c|c|c|c|}
\hline \multicolumn{13}{|c|}{ Pengamatan Organoleptis yang diamati } \\
\hline Hari & & Bentuk & & & Warna & & & Bau & & & Rasa & \\
\hline ke- & FS1 & FS2 & FS3 & FS1 & FS2 & FS3 & FS1 & FS2 & FS3 & FS1 & FS2 & FS3 \\
\hline 1 & $\begin{array}{c}\text { Serbuk } \\
\text { halus }\end{array}$ & $\begin{array}{c}\text { Serbuk } \\
\text { halus }\end{array}$ & $\begin{array}{c}\text { Serbuk } \\
\text { halus }\end{array}$ & Coklat & $\begin{array}{l}\text { Coklat } \\
\text { Putih }\end{array}$ & $\begin{array}{l}\text { Coklat } \\
\text { Putih }\end{array}$ & $\begin{array}{l}\text { Khas } \\
\text { daun }\end{array}$ & $\begin{array}{l}\text { Khas } \\
\text { daun }\end{array}$ & $\begin{array}{l}\text { Khas } \\
\text { daun }\end{array}$ & $\begin{array}{l}\text { Manis } \\
\text { segar }\end{array}$ & $\begin{array}{l}\text { Manis } \\
\text { segar }\end{array}$ & $\begin{array}{l}\text { Manis } \\
\text { segar }\end{array}$ \\
\hline 3 & $\begin{array}{l}\text { Serbuk } \\
\text { halus }\end{array}$ & $\begin{array}{c}\text { Serbuk } \\
\text { halus }\end{array}$ & $\begin{array}{c}\text { Serbuk } \\
\text { halus }\end{array}$ & Coklat & $\begin{array}{l}\text { Coklat } \\
\text { Putih }\end{array}$ & $\begin{array}{l}\text { Coklat } \\
\text { Putih }\end{array}$ & $\begin{array}{l}\text { Khas } \\
\text { daun }\end{array}$ & $\begin{array}{l}\text { Khas } \\
\text { daun }\end{array}$ & $\begin{array}{l}\text { Khas } \\
\text { daun }\end{array}$ & $\begin{array}{l}\text { Manis } \\
\text { segar }\end{array}$ & $\begin{array}{l}\text { Manis } \\
\text { segar }\end{array}$ & $\begin{array}{l}\text { Manis } \\
\text { segar }\end{array}$ \\
\hline 6 & $\begin{array}{c}\text { Serbuk } \\
\text { halus }\end{array}$ & $\begin{array}{c}\text { Serbuk } \\
\text { halus }\end{array}$ & $\begin{array}{c}\text { Serbuk } \\
\text { halus }\end{array}$ & Coklat & $\begin{array}{l}\text { Coklat } \\
\text { Putih }\end{array}$ & $\begin{array}{l}\text { Coklat } \\
\text { Putih }\end{array}$ & $\begin{array}{l}\text { Khas } \\
\text { daun }\end{array}$ & $\begin{array}{l}\text { Khas } \\
\text { daun }\end{array}$ & $\begin{array}{l}\text { Khas } \\
\text { daun }\end{array}$ & $\begin{array}{l}\text { Manis } \\
\text { segar }\end{array}$ & $\begin{array}{l}\text { Manis } \\
\text { segar }\end{array}$ & $\begin{array}{l}\text { Manis } \\
\text { segar }\end{array}$ \\
\hline 9 & $\begin{array}{c}\text { Serbuk } \\
\text { halus }\end{array}$ & $\begin{array}{c}\text { Serbuk } \\
\text { halus }\end{array}$ & $\begin{array}{c}\text { Serbuk } \\
\text { halus }\end{array}$ & Coklat & $\begin{array}{l}\text { Coklat } \\
\text { Putih }\end{array}$ & $\begin{array}{l}\text { Coklat } \\
\text { Putih }\end{array}$ & $\begin{array}{l}\text { Khas } \\
\text { daun }\end{array}$ & $\begin{array}{l}\text { Khas } \\
\text { daun }\end{array}$ & $\begin{array}{l}\text { Khas } \\
\text { daun }\end{array}$ & $\begin{array}{l}\text { Manis } \\
\text { segar }\end{array}$ & $\begin{array}{l}\text { Manis } \\
\text { segar }\end{array}$ & $\begin{array}{l}\text { Manis } \\
\text { segar }\end{array}$ \\
\hline 12 & $\begin{array}{l}\text { Serbuk } \\
\text { halus }\end{array}$ & $\begin{array}{c}\text { Serbuk } \\
\text { halus }\end{array}$ & $\begin{array}{c}\text { Serbuk } \\
\text { halus }\end{array}$ & Coklat & $\begin{array}{l}\text { Coklat } \\
\text { Putih }\end{array}$ & $\begin{array}{l}\text { Coklat } \\
\text { Putih }\end{array}$ & $\begin{array}{l}\text { Khas } \\
\text { daun }\end{array}$ & $\begin{array}{l}\text { Khas } \\
\text { daun }\end{array}$ & $\begin{array}{l}\text { Khas } \\
\text { daun }\end{array}$ & $\begin{array}{l}\text { Manis } \\
\text { segar }\end{array}$ & $\begin{array}{l}\text { Manis } \\
\text { segar }\end{array}$ & $\begin{array}{l}\text { Manis } \\
\text { segar }\end{array}$ \\
\hline 15 & $\begin{array}{c}\text { Serbuk } \\
\text { halus }\end{array}$ & $\begin{array}{c}\text { Serbuk } \\
\text { halus }\end{array}$ & $\begin{array}{c}\text { Serbuk } \\
\text { halus }\end{array}$ & Coklat & $\begin{array}{l}\text { Coklat } \\
\text { Putih }\end{array}$ & $\begin{array}{l}\text { Coklat } \\
\text { Putih }\end{array}$ & $\begin{array}{l}\text { Khas } \\
\text { daun }\end{array}$ & $\begin{array}{l}\text { Khas } \\
\text { daun }\end{array}$ & $\begin{array}{l}\text { Khas } \\
\text { daun }\end{array}$ & $\begin{array}{l}\text { Manis } \\
\text { segar }\end{array}$ & $\begin{array}{l}\text { Manis } \\
\text { segar }\end{array}$ & $\begin{array}{l}\text { Manis } \\
\text { segar }\end{array}$ \\
\hline 18 & $\begin{array}{c}\text { Serbuk } \\
\text { halus }\end{array}$ & $\begin{array}{c}\text { Serbuk } \\
\text { halus }\end{array}$ & $\begin{array}{c}\text { Serbuk } \\
\text { halus }\end{array}$ & Coklat & $\begin{array}{l}\text { Coklat } \\
\text { Putih }\end{array}$ & $\begin{array}{l}\text { Coklat } \\
\text { Putih }\end{array}$ & $\begin{array}{l}\text { Khas } \\
\text { daun }\end{array}$ & $\begin{array}{l}\text { Khas } \\
\text { daun }\end{array}$ & $\begin{array}{l}\text { Khas } \\
\text { daun }\end{array}$ & $\begin{array}{l}\text { Manis } \\
\text { segar }\end{array}$ & $\begin{array}{l}\text { Manis } \\
\text { segar }\end{array}$ & $\begin{array}{l}\text { Manis } \\
\text { segar }\end{array}$ \\
\hline 21 & $\begin{array}{c}\text { Serbuk } \\
\text { halus }\end{array}$ & $\begin{array}{c}\text { Serbuk } \\
\text { halus }\end{array}$ & $\begin{array}{c}\text { Serbuk } \\
\text { halus }\end{array}$ & Coklat & $\begin{array}{l}\text { Coklat } \\
\text { Putih }\end{array}$ & $\begin{array}{l}\text { Coklat } \\
\text { Putih }\end{array}$ & $\begin{array}{l}\text { Khas } \\
\text { daun }\end{array}$ & $\begin{array}{l}\text { Khas } \\
\text { daun }\end{array}$ & $\begin{array}{l}\text { Khas } \\
\text { daun }\end{array}$ & $\begin{array}{l}\text { Manis } \\
\text { segar }\end{array}$ & $\begin{array}{l}\text { Manis } \\
\text { segar }\end{array}$ & $\begin{array}{l}\text { Manis } \\
\text { segar }\end{array}$ \\
\hline
\end{tabular}

Ket: FS= Formulasi Sampel 
Berdasarkan hasil pengamatan yang tertera pada Tabel 1 menunjukkan hasil uji organoleptik sediaan serbuk instan dengan bahan daun sirsak (Annona muricata L.) dan sari buah nanas (Ananas comosus L.) yang telah diamati bentuk, warna, bau, dan rasa selama 3 minggu secara visual, proses pengamatan dilakukan setiap 3 hari sekali.

\section{Uji Kesukaan}

Tabel 2 Hasil Uji Kesukaan

\begin{tabular}{|c|c|c|c|c|c|c|}
\hline \multirow[t]{2}{*}{ No } & \multirow[t]{2}{*}{ Parameter yang Diuji } & \multirow[t]{2}{*}{ Skala Hedonik } & \multirow[t]{2}{*}{ Skor } & \multicolumn{3}{|c|}{ Hasil } \\
\hline & & & & FS1 (\%) & FS2 (\%) & FS3 (\%) \\
\hline \multirow[t]{5}{*}{1} & Warna & Sangat Suka & 5 & 40 & 40 & 40 \\
\hline & & Suka & 4 & 40 & 60 & 60 \\
\hline & & Agak Suka & 3 & 20 & 0 & 0 \\
\hline & & Tidak Suka & 2 & 0 & 0 & 0 \\
\hline & & Sangat Tidak Suka & 1 & 0 & 0 & 0 \\
\hline \multirow[t]{5}{*}{2} & Aroma & Sangat Suka & 5 & 26,67 & 26,67 & 26,67 \\
\hline & & Suka & 4 & 60 & 60 & 60 \\
\hline & & Agak Suka & 3 & 13,33 & 13,33 & 13,33 \\
\hline & & Tidak Suka & 2 & 0 & 0 & 0 \\
\hline & & Sangat Tidak Suka & 1 & 0 & 0 & 0 \\
\hline \multirow[t]{5}{*}{3} & Rasa & Sangat Suka & 5 & 46,66 & 53,33 & 53,33 \\
\hline & & Suka & 4 & 40 & 33,33 & 33,33 \\
\hline & & Agak Suka & 3 & 6,67 & 6,67 & 6,67 \\
\hline & & Tidak Suka & 2 & 6,67 & 6,67 & 6,67 \\
\hline & & Sangat Tidak Suka & 1 & 0 & 0 & 0 \\
\hline
\end{tabular}

Ket: FS = Forumulasi Sampel

Berdasarkan hasil pengamatan yang tertera pada Tabel 2 menunjukan hasil uji kesukaan dengan panelis agak terlatih terdiri dari 15 orang terhadap sediaan serbuk instan daun sirsak (Anona muricata
L) dan sari buah nanas (Ananas comosus L.) dengan parameter yang diuji yaitu warna, aroma, dan rasa. Untuk lebih jelasnya dapat dilihat dalam diagram di bawah ini:

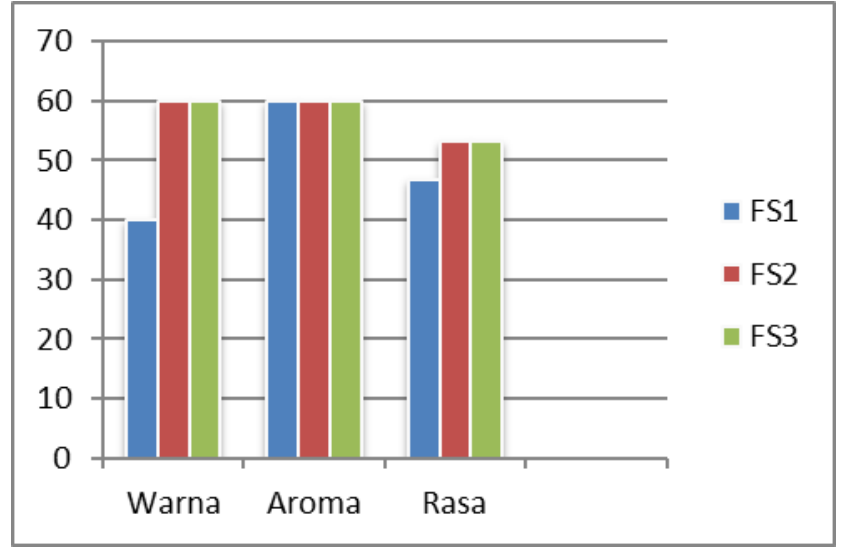

Gambar 1 Diagram Hasil Uji Kesukaan 


\section{PEMBAHASAN}

\section{Uji Organoleptik}

Berdasarkan data pengamatan pada Tabel 1 merupakan hasil pembuatan serbuk instan dengan perlakuan F3 yang dibuat sebanyak 3 sampel. Dapat dilihat dari hasil uji organoleptik sediaan yang telah dilakukan dan diamati peneliti selama 3 minggu secara visual, tidak mengalami perubahan.

Pada hasil pengamatan hari ke-1 sampai dengan hari ke-21, ketiga sampel tersebut tidak menunjukan perubahan baik bentuk, warna, bau dan rasa. Tidak terjadinya perubahan setelah uji organoleptik tersebut, disebabkan karena pada tahapan dalam penyiapan bahan serta proses pembuatan sediaan sesuai dengan penelitian $^{[13]}$ yang menyatakan bahwa kelarutan serbuk instan berhubungan dengan banyaknya air yang terkandung dalam bahan, dimana semakin tinggi kadar air kelarutan cenderung semakin kecil. Kadar air juga merupakan salah satu karakteristik yang sangat penting pada bahan pangan, karena air dapat mempengaruhi penampakan, tekstur, dan citarasa pada bahan pangan[14]. Kadar air suatu bahan pangan merupakan salah satu faktor yang dapat menentukan tingkat keawetan selama penyimpanan dan kadar air yang rendah dapat memperlambat petumbuhan mikroorganisme sehingga bahan pangan tersebut dapat bertahan lama[15].

Berdasarkan hasil sediaan, formulasi sari buah nanas yang digunakan untuk pembuatan serbuk instan lebih sedikit dibandingkan dengan ektrak daun sirsak dan menggunakan buah nanas dapat meningkatkan daya tahan simpan atau bersifat mengawetkan sehingga menunjukkan bahwa sediaan serbuk instan yang dibuat peneliti stabil dalam penyimpanan selama 3 minggu.

\section{Uji Kesukaan}

Uji kesukaan serbuk instan untuk parameter warna, berdasarkan data yang diperoleh diketahui bahwa panelis menyukai sampel FS1 dengan jumlah penilaian 40\% (cukup), sampel FS2 dengan jumlah penilaian $60 \%$ (cukup), dan sampel FS3 dengan jumlah penilaian 60\% (cukup). Dari hasil penilaian, dapat dilihat bahwa sampel FS2 dan FS3 lebih disukai dibandingkan dengan sampel FS1 dari segi parameter warnanya. Uji kesukaan untuk parameter aroma, berdasarkan data yang diperoleh diketahui bahwa panelis menyukai ketiga sampel tersebut dengan jumlah penilaian 60\% (cukup). Uji kesukaan untuk parameter rasa, berdasarkan data yang diperoleh diketahui bahwa panelis sangat menyukai sampel FS1 dengan jumlah penilaian 46,66\% (cukup), sampel FS2 dengan jumlah penilaian 53,33\% (cukup), dan sampel FS3 dengan jumlah penilaian $53,33 \%$ (cukup). Dari hasil penilaian, dapat dilihat bahwa sampel FS2 dan FS3 lebih disukai dibandingkan dengan sampel FS1 dari segi parameter rasanya. Menurut[16] suatu produk dapat diterima oleh konsumen apabila memiliki rasa yang sesuai dengan yang diinginkan.

Berdasarkan hasil pengamatan uji kesukaan diperoleh data bahwa dari warna, aroma, dan rasa serbuk instan dengan perlakuan F3 yang dibuat sebanyak 3(tiga) sampel tersebut disukai dan dapat diterima oleh masyarakat. Faktor yang mempengaruhi rasa dari sebuk instan daun sirsak dan buah nanas yaitu rasa manis yang dipengaruhi oleh penambahan glukosa dan sukrosa serta rasa asam yang berasal dari bahan buah nanas. Hal ini sesuai dengan penelitian ${ }^{[17]}$ yang menyatakan bahwa adanya glukosa dan sukrosa dapat meningkatkan cita rasa pada bahan produk pangan. Rasa manis dari sukrosa bersifat murni sebab tidak meninggalkan after taste pada produk pangan[18].

\section{Dosis Terhadap Sediaan}

Berdasarkan penelitian ${ }^{[19]}$ menyatakan bahwa pemberian air rebusan daun sirsak yang digunakan untuk menurunkan kadar asam urat dengan dosis 6 gram daun sirsak, oleh karena itu penentuan dosis yang efektif juga dilakukan dengan membuat ekstrak daun sirsak pada formulasi ketiga dengan perhitungan daun sirsak yang digunakan sebanyak 20 gr yang kemudian dibuat menjadi $375 \mathrm{ml}$ sediaan ektrak daun sirsak. ${ }^{[20]}$ menyatakan dosis 
pemberian ekstrak buah nanas $500 \mathrm{mg} / \mathrm{kg}$ BB dan $1000 \mathrm{mg} / \mathrm{kg}$ BB selama 7 hari dapat menurunkan kadar asam urat pada tikus putih jantan, oleh karena itu dikonversikan dosis pemberian buah nanas untuk manusia sebanyak 45 gr. Penentuan dosis yang efektif dilakukan dengan membuat sari buah nanas pada formulasi ketiga dengan perhitungan buah nanas yang digunakan sebanyak 50 gr yang kemudian dibuat menjadi $125 \mathrm{ml}$ sediaan sari buah nanas. Penggunaan buah nanas tersebut mampu menutupi bau dan rasa pahit yang dihasilkan oleh daun sirsak.

Berdasarkan hasil perhitungan komposisi pada daun sirsak dan buah nanas tersebut, berat instan yang dihasilkan sebanyak 168 gr. Bobot serbuk instan yang digunakan dalam 1 (satu) kemasan sebanyak $10 \mathrm{gr}$, dengan komposisi daun sirsak setara dengan 1,2 gr dan buah nanas setara dengan 2,97 gr. Dari hasil perhitungan dosis, maka sediaan serbuk instan daun sirsak dikombinasikan dengan sari buah nanas ini dapat diminum sebanyak 1-5 kemasan perhari. Berdasarkan hasil perhitungan, sediaan serbuk instan yang dibuat dari daun sirsak dikombinasikan dengan sari buah nanas mampu mencegah peningkatan kadar asam urat, sehingga seharusnya dilakukan lebih lanjut mengenai uji khasiat terhadap sediaan.

\section{SIMPULAN}

Berdasarkan hasil pengamatan dan analisis data yang dilakukan maka dapat disimpulkan bahwa sediaan serbuk instan yang berhasil dibuat dari daun sirsak yang dikombinasikan dengan sari buah nanas untuk mencegah peningkatan kadar asam urat yaitu ketentuan formulasi 3 (sari buah nanas $125 \mathrm{ml}$, ekstrak daun sirsak $375 \mathrm{ml}$, dan penambahan gula sebanyak 200 gr). Hasil uji organoleptik dari perlakuan formulasi 3 yang dibuat sebanyak 3 sampel tidak menunjukkan perubahan yang signifikan. Hasil uji kesukaan menunjukkan sampel yang banyak disukai yaitu sampel FS2 dan FS3 dikarenakan warna sediaan yang diseduh tidak lebih pekat dibandingkan dengan sampel FS3.
Berdasarkan hasil penelitian ini, sediaan serbuk instan dari ketiga sampel tersebut peneliti memilih sampel FS2, karena menghasilkan sediaan sebanyak 168 gram serta sediaan tersebut lebih disukai dan dapat diterima oleh masyarakat. Dari hasil penghitungan akhir, dosis pemakaian serbuk instan daun sirsak dikombinasikan dengan sari buah nanas untuk mencegah peningkatan kadar asam urat yaitu sebesar 10 gram dalam satu bungkus serbuk instan dapat diminum sebanyak 1-5 bungkus untuk satu hari pemakaian.

\section{SARAN}

Berdasarkan penelitian yang telah dilakukan, perlu diperhatikan mengenai perbandingan terhadap penambahan filtran dengan gula yang sebaiknya yaitu 1:1, dengan memperhatikan penambahan bahan yang optimal dapat memperbaiki sifat fisik serbuk instan. Pemilihan bahan untuk pembuatan serbuk instan perlu diperhatikan juga, sehingga menghasilkan sediaan serbuk instan yang baik sesuai dengan penelitian yang dilakukan, dan dalam penelitian lanjutan disarankan untuk dapat memahami pengamatan mengenai uji khasiat terhadap sediaan.

\section{DAFTAR PUSTAKA}

1. Ilkafah, I. (2017). Efektivitas Daun Sirsak Dalam Menurunkan Nilai Asam Urat Dan Keluhan Nyeri Pada Penderita Gout Di Kelurahan Tamalanrea Makassar. PHARMACON, 6(2).

2. Kowalak, Welsh \& Mayer. (2011). Buku Ajar Patofisiologi. Jakarta: EGC.

3. Widyanto, F. W. (2017). Artritis gout dan perkembangannya. Saintika Medika: Jurnal Ilmu Kesehatan dan Kedokteran Keluarga, 10(2), 145-152.

4. Sammulia, S. F., \& Suhaera, S. (2019). Pencegahan dan Pengendalian Hipertensi dan Asam Urat Ringan Melalui Tanaman Obat Keluarga (TOGA). JPPM (Jurnal Pengabdian dan Pemberdayaan Masyarakat), 3(2), 201-204.

5. Lina \& Juwita. (2012). Ramuan \& Khasiat Sirsak. Jakarta: Penebar Swadaya. 
6. Suwandi, J. F., \& Irfa, R. (2016). Studi Pustaka Khasiat Daun Sirsak (Annona muricata) dalam Menurunkan Nyeri pada Pasien Gout Arthritis. Jurnal Majority, 5(3), 145-150.

7. Shabella R. (2011). Terapi daun sirsak. Klaten: Galmas Publisher.

8. Apriana, R., Retnaingsih, D., \& Supriyanto, J. (2017). Pengaruh Rebusan Daun Sirsak Untuk Menurunkan Nyeri Gout Atrhitis Pada Lansia. In Prosiding Seminar Nasional \& Internasional (Vol. 1, No. 1).

9. Sekarindah, Rozaline. (2009). Terapi Jus Buah Dan Sayur. Depok: Puspa Swara, Anggota Ikapi

10. Sevilia, D. A. V. D., \& Dwiningtyas, M. (2016). Pengaruh Konsumsi Jus Nanas Terhadap Penurunan Kadar Asam Urat Pada Lansia Di UPT Panti Werdha Mojopahit Mojokerto. Jurnal Ilmiah Keperawatan (Scientific Journal of Nursing), 2(1), 36-42.

11. Darwis, R. S. (2016). Membangun desain dan model action research dalam studi dan aksi pemberdayaan masyarakat. KOMUNIKA: Jurnal Dakwah dan Komunikasi, 10(1), 142153.

12. Mulyadi, A. F., Wijana, S., \& Fajrin, L. L. (2015). Pemanfaatan Nanas (Ananas Comosus L.) Subgrade Sebagai Fruit Leather Nanas Guna Mendukung Pengembangan Agroindustri di Kediri: Kajian Penambahan Karaginan Dan Sorbitol. Jurnal Agroteknologi, 9(02), 112-122.

13. Haryanto, B. (2018). Pengaruh Penambahan Gula Terhadap Karakteristik Bubuk Instan Daun Sirsak (Annona muricata L.) dengan Metode Kristalisasi. Jurnal Penelitian Pascapanen Pertanian, 14(3), 163170.

14. Winarno, F.G. (2002). Kimia Pangan dan Gizi. PT. Gramedia Pustaka Utama. Jakarta.

15. Dharmaputra, O. S. (1994). Kapang pada beras yang berasal dari beberapa varietas padi. Hayati, 1(2), 37-41.

16. Sagala, M. A., Efendi, R \& Yusmarini. (2016). Perbedaan cara ekstraksi jahe dan penambahan gula kelapa terhadap mutu sirup jahe. Jurnal Faperta, 3(1), 1-10.

17. Wijana, S., Mulyadi, A. F., \& Septivirta, T. D. T. (2014). Pembuatan permen jelly dari buah nanas (Ananas comosus L.) subgrade (kajian konsentrasi karagenan dan gelatin). Universitas Brawijaya.

18. Winarno, F.G. (2004). Kimia Pangan dan Gizi. PT. Gramedia Pustaka Utama. Jakarta.

19. Nursoleha, N., Yani, A., \& Hermanto, R. A. (2019). PENGARUH PEMBERIAN AIR REBUSAN DAUN SIRSAK (Annona muricata L) TERHADAP PENURUNAN KADAR ASAM URAT PADA PASIEN RAWAT JALAN DI PUSKESMAS PASAWAHAN. Journal of Holistic and Health Sciences, 3(1), 21-29.

20. Rasyad, A. A., \& Erjon, N. (2019). Pengaruh pemberian ekstrak nanas (Ananas comocus (L.) Merr) terhadap penurunan kadar asam urat pada tikus jantan hiperurisemia. Jurnal Ilmiah Farmasi, 15(2), 64-69. 